Revista Eletrônica Geografar, Curitiba, v. 2, Resumos do VI Seminário Interno de Pós-Graduação em Geografia, p. 72-72. Junho/2007

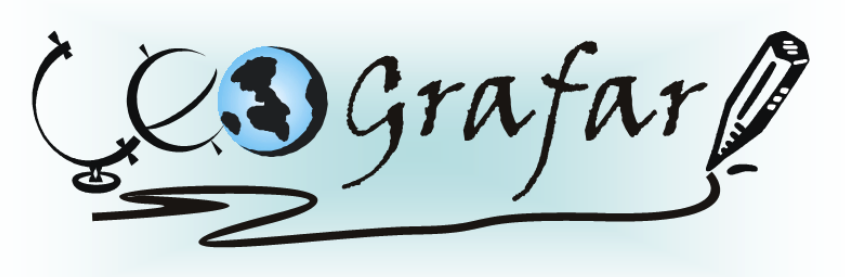

Revista Eletrônica do Programa de Pós-Graduação em Geografia - UFPR

\title{
OSCILAÇÕES CLIMÁTICAS NO QUATERNÁRIO E AS IMPLICAÇÕES NO RELEVO DA BACIA HIDROGRÁFICA DO ALTÍSSIMO RIO TIBAGI - PR
}

\section{TIAGO DAMAS MARTINS ${ }^{1}$}

Nesta pesquisa busca-se através de análise de campo e gabinete comprovar a ação de oscilações climáticas pretéritas, como determinantes em aspectos da estrutura e origem da morfologia atual do relevo e de suas implicações na evolução da paisagem. $O$ estudo abrange um recorte temporal referente ao Período Quaternário, do qual existem diversas referências em que são evidenciadas constantes oscilações climáticas, interpretação esta que oferece uma relação direta com o quadro natural que conhecemos no presente, razão pela qual o estudo do Quaternário mostra-se fundamental. A metodologia de integração cartográfica utilizada e os levantamentos de campo baseiam-se em proposta conceitual que sugere como forma e evolução policíclica das vertentes e do relevo atuais a partir de oscilações climáticas pretéritas. A pesquisa neste sentido busca identificar nas superfícies de aplainamento evidências no relevo relacionadas a processos que caracterizem tais oscilações. A área em estudo localiza-se na porção centro-sul do Estado do Paraná, na unidade de paisagem de caráter paleogeográfico (relictual) identificada como Campos Gerais, no Segundo Planalto Paranaense. Para esta pesquisa o projeto contempla a caracterização dos elementos do meio físico onde se localizam as nascentes do rio Tibagi, o qual tem uma extensão total de 550 quilômetros, percorrendo o estado em direção do sul para norte, até sua foz no Rio Paranapanema. A área em análise é delimitada na porção mais oriental pela bacia do referido rio, sendo neste estudo considerada como Bacia do Altíssimo Rio Tibagi, abrangendo uma superfície de $72,93 \mathrm{~km}^{2}$. A base cartográfica para a caracterização do meio físico, com ênfase no levantamento geomorfológico é constituída por: ortocarta-imagens e cartas topográficas e geológicas em escala 1: 50.000. Os mapas temáticos estão sendo elaborados e manipulados em ambiente de sistema de informação geográfica. Para apoio das análises de gabinete estão sendo desenvolvidas atividades de campo com documentação fotográfica.

Palavras-Chave: Altíssimo Rio Tibagi. Campos Gerais. Geomorfologia Climática.

${ }^{1}$ Mestrando em Geografia - UFPR - email:tiago-damas@hotmail.com Orientador: EVERTON PASSOS 